\title{
ПОДАТКОВА ДЕЦЕНТРАЛІЗАЦІЯ ЯК ЧИННИК ФОРМУВАННЯ ФІНАНСОВОЇ БАЗИ ТЕРИТОРІЙ
}

Галамай Роман Ярославович аспірант

Львівський національний університет імені Івана Франка (м. Львів, Україна) ORSID 0000-0003-0120-696X galamaj0017@gmail.com

\begin{abstract}
У статті досліджено питання впливу податків на зборів на формування фінансової бази територій на локальному, субрегіональному та регіональному рівнях. Визначено нормативи зарахування основних податкових надходжень до державного та місиевих бюджетів. Розглянуто систему міжбюджетних трансфертів та вплив на їх формування окремих податків. Проаналізовано систему встановлення на державному рівні пільг з сплати місцевих податків, які призводять до розбалансування місцевих бюджетів. Визначено недоліки системи формування власних доходів місцевих бюджетів, які зменшують можливість отримання в повному обсязі доходів місцевих бюджетів та досягнення реальної бюджетної самодостатності. Запропоновані методи посилення мотивації місцевих громад до ефективного використання місцевих ресурсів та власних можливостей. Надано пропозиції щодо усунення недоліків існуючої системи міжбюджетних трансфертів, що порушують справедливість фінансового вирівнювання та не відіграють стимулюючої ролі для розвитку.
\end{abstract}

Ключові слова: податки, збори, децентралізація, території, міжбюджетні трансферти.

DOI: https://doi.org/10.32845/bsnau.2019.3.10

Постановка проблеми. Потреба децентралізації державного управління, в тому числі бюджетно-фінансової децентралізації, стоїть на порядку денному з перших років незалежності України. На початку 1990-х років всі міста, села селища стали самостійними адміністративно-територіальними одиницями, що призвело до надмірного подрібнення та створення більше 10 тисяч сільських громад з середньою кількістю мешканців близько 1500 осіб. Обмеженість реального контролю органів місцевого самоврядування щодо своїх бюджетів призвели до невизначеності в розподілі повноважень та відповідальності між рівнями влади, насамперед в сферах освіти та охорони здоров'я, транспорту, соціального забезпечення, економічного розвитку. Застосування видаткових нормативів при формуванні бюджетів та покриття з державного бюджету різниці між видатками та доходами не створювали умов для стимулювання органів місцевого самоврядування в економічному розвитку.

Відповідно до ухваленого в 2015 році Закону України "Про добровільне об'єднання територіальних громад" почалося створення ОТГ і передача повноважень та ресурсів органам місцевого самоврядування, в першу чергу податкових ресурсів, які дають змогу власного розвитку територій та впливу на зміцнення фінансової бази. Наступною стадією утворення територій держави є укрупнення районного рівня. Регіональний рівень планується залишити в існуючих межах. Важливим питанням $€$ функціональна база на різних рівнях управління та створення їх фрінансового плацдарму для виконання покладених повноважень.

Аналіз останніх досліджень та публікацій. Дослідженням питання розвитку податкової системи та її впливу на формування фінансової бази територій досліджувало багато вчених, серед яких В. Андрущенко, 3. Варналій, В. Геєць, О. Василик, П. Мельник, Х. Патицька, А. Соколовська та інші. Питанню реформи місцевого самоврядування присвятили свої праці такі вчені як П. Жук, А. Пелехатий, О. Раделицький та інші. Проте, питання розвитку податкової системи в умовах реформи місцевого самоврядування вимагає особливої

уваги, оскільки змінюються пріоритети її функціонування.

Мета статті є дослідження впливу податкової системи на формування фінансової бази територій.

Виклад основного матеріалу. Кінець 2014 року ознаменувався ухваленням Закону України "Про внесення змін до Бюджетного кодексу України щодо реформи міжбюджетних відносин", який розпочав бюджетну децентралізацію через механізм переходу бюджетів об'єднаних громад на прямі міжбюджетні відносини з державними бюджетом - в 2018 році прямі міжбюджетні відносини, як і 24 обласні бюджети, 148 бюджетів міст обласного значення, бюджет м. Києва та 450 районних бюджетів, мають 665 бюджетів ОТГ.

За період з початку бюджетної децентралізації новації бюджетного та податкового законодавства базувались в основному на формуванні дохідної бази місцевих бюджетів:

- встановлено норматив відрахування податку на прибуток підприємств приватної форми власності (10\% для обласних бюджетів);

- зменшено норматив відрахування в місцеві бюджети податків та зборів з фізичних осіб з 100\% до 75\% (15\% в обласні бюджети, $60 \%$ в бюджети районів, міст обласного значення та ОТГ);

- встановлено норматив відрахувань з рентної плати за користування надрами загальнодержавного значення для видобування нафти, природного газу (5\%) та видобування інших копалин (25\%);

- встановлено норматив відрахувань з акцизного податку з виробленого чи ввезеного на територію України пального (13,44\%), запроваджено акцизний податок з реалізації в роздрібній торгівлі (5\% від вартості);

- віднесено до місцевих податків податок на майно, єдиний податок, інші відрахування.

В результаті проведених змін щодо формування дохідної бази бюджетів, нормативи зарахування основних податкових надходжень до державного та місцевих бюджетів значно змінили свою структуру зарахувань на різні рівні територій (табл. 1). 
Таблиця 1

Структура зарахування податків та зборів до місцевих бюджетів територій [1]

\begin{tabular}{|c|c|c|c|c|c|c|}
\hline \multirow[b]{2}{*}{ Вид платежів } & \multirow[b]{2}{*}{$\begin{array}{l}\text { ДЕРЖАВНИЙ } \\
\text { БЮДЖЕТ }\end{array}$} & \multicolumn{5}{|c|}{ МІСЦЕВІ БЮДЖЕТИ } \\
\hline & & М.КИїВ & ОБЛАСТЬ & $\begin{array}{l}\text { ОТГ, МІСТО } \\
\text { ОБЛ. } \\
\text { ЗНАЧЕННЯ }\end{array}$ & РАЙOH & \begin{tabular}{|l} 
СЕЛО, СЕЛИЩЕ, \\
МІСТО РАЙ. \\
ЗНАЧЕННЯ
\end{tabular} \\
\hline Податок та збір на доходи фізичних осіб * & $25 \%$ & $40 \%$ & $15 \%$ & $60 \%$ & $60 \%$ & \\
\hline $\begin{array}{l}\text { Податок на прибуток (крім підприємств державної та } \\
\text { комунал.власності) }\end{array}$ & $90 \%$ & $10 \%$ & $10 \%$ & & & \\
\hline $\begin{array}{l}\text { Податок на прибуток підприємств та установ державної та } \\
\text { комунальної власності }\end{array}$ & $100 \%$ & $100 \%$ & $100 \%$ & $100 \%$ & $100 \%$ & $100 \%$ \\
\hline Податок на додану вартість з вироблених в Україні товарів & $100 \%$ & & & & & \\
\hline $\begin{array}{l}\text { Податок на додану вартість з ввезених на територію } \\
\text { України товарів }\end{array}$ & $100 \%$ & & & & & \\
\hline $\begin{array}{l}\text { Рентна плата за використання лісових ресурсів головного } \\
\text { користування }\end{array}$ & $50 \%$ & $50 \%$ & $50 \%$ & & & \\
\hline Рентна плата за використання лісових ресурсів & & $100 \%$ & & $100 \%$ & & $100 \%$ \\
\hline Рентна плата за спеціальне використання води & $55 \%$ & $45 \%$ & $45 \%$ & & & \\
\hline $\begin{array}{l}\text { Рентна плата за спеціальне використання води водних } \\
\text { об'єктів місцевого значення }\end{array}$ & & $100 \%$ & & $100 \%$ & & $100 \%$ \\
\hline $\begin{array}{l}\text { Рентна плата за корист. надрами для видобування копалин } \\
\text { загальнодерж.значення }\end{array}$ & $75 \%$ & $25 \%$ & $25 \%$ & & & \\
\hline $\begin{array}{l}\text { Рентна плата за користування надрами для видобування } \\
\text { копалин місц. значення }\end{array}$ & & $100 \%$ & & $100 \%$ & & $100 \%$ \\
\hline $\begin{array}{l}\text { Рентна плата за користування надрами для видобування } \\
\text { нафтт, газу }\end{array}$ & $95 \%$ & & $2 \%$ & $3 \%$ & $2 \%$ & $1 \%$ \\
\hline Плата за використання інших природних ресурсів & & $100 \%$ & $100 \%$ & & & \\
\hline $\begin{array}{l}\text { Акцизний податок з вироблених та ввезених в Україну } \\
\text { підакцизних товарів (крім пального) }\end{array}$ & $100 \%$ & & & & & \\
\hline $\begin{array}{l}\text { Акцизний податок з вироблених та ввезених в Україну } \\
\text { підакцизних товарів (пальне) }\end{array}$ & $86,6 \%$ & $13,4 \%$ & & $13,4 \%$ & & $13,4 \%$ \\
\hline $\begin{array}{l}\text { Акцизний податок з реалізації суб'єктами роздрібної } \\
\text { торгівлі підакцизних товарів }\end{array}$ & & $100 \%$ & & $100 \%$ & & $100 \%$ \\
\hline Екологічний податок * & $45 \%$ & $55 \%$ & $30 \%$ & $25 \%$ & & $25 \%$ \\
\hline $\begin{array}{l}\text { Місцеві податки та збори (податки на майно, єдиний } \\
\text { податок, турист.збір, інші) }\end{array}$ & & $100 \%$ & & $100 \%$ & & $100 \%$ \\
\hline
\end{tabular}

* нормативи зарахування окремих податків до державного та місцевих бюджету, крім м,Києва;

Також до доходів місцевих бюджетів були передані 3 державного бюджету частина неподаткових надходжень $100 \%$ державного мита та плати за надання більшості адміністративних послуг. Громади дістали право розпоряджатися землями поза межами населених пунктів, самостійно регулювати ставки податків на нерухомість та надавати пільги по їх сплаті. Законодавчими змінами надано органам місцевого самоврядування можливість затверджувати свої бюджети незалежно від того, чи прийнято закон про Державний бюджет України на відповідний рік; розширено право місцевих органів влади здійснювати зовнішні запозичення (раніше таке право мали лише міські ради міст з чисельністю населення понад 300 тисяч жителів); відмінено систему індикативного планування Міністерством фінансів України показників місцевих бюджетів.

3 метою стимулювання територіальних громад до об'єднання та переходу на прямі міжбюджетні відносини 3 державним бюджетом запроваджено підтримку з державного бюджету розвитку інфраструктури об'єднаних територіальних громад.

3 метою перерозподілу фінансових ресурсів між бюджетами для вирівнювання дисбалансів в їх доходах, що виникають внаслідок відмінностей у ресурсному потенціалі регіонів, нерівномірного розміщення виробничої бази та особливостей історичного розвитку держави, передбачаються мі- жбюджетні трансферти - кошти, які безоплатно і безповоротно передаються з одного бюджету до іншого у виді дотацій (з метою покриття бюджетного дефріциту) або субвенцій (з цільовим призначенням для здійснення спільного фінансування певного заходу).

З 2015 року діє нова система міжбюджетних трансфертів, яка змінила підходи до бюджетного вирівнювання - перехід від системи вирівнювання місцевих бюджетів «за видатками» до системи вирівнювання «за доходами» (залежно від рівня надходжень на одного жителя). Частка всіх трансфертів з початку бюджетної децентралізації знаходиться на рівні 55$60 \%$ доходів місцевих бюджетів, що є дещо вище від аналогічних показників подібних за розмірами території, кількістю населення та структурою державної влади країн (48-50\% в Польщі). Так, на 2018 рік в Державному бюджеті України для забезпечення видатків, закріплених за місцевими бюджетами, передбачені трансферти на суму 308,9 млрд. грн., що становить $57,4 \%$ їх загальних доходів:

1) базова дотація (8,2 млрд грн) (Середній рівень надходжень на 1 жителя, який використовувався при розрахунку дотацій на 2018 рік, склав по податку на доходи фізичних осіб (ПДФО) для обласних бюджетів 376,6 грн, для місцевих бюджетів інших рівнів - 1506,41 грн, по податку на прибуток підприємств для обласних бюджетів - 76,83 грн. На 2018 рік 
не здійснювалося вирівнювання по 134 з 1287 місцевих бюджетах, базову дотацію визначено для 930 бюджетів, реверСну - для 223).

2) освітня субвенція (61,7 млрд грн) - (в 2018 році не більше 9,3 тис. грн. без врахування можливих коригуючих коесіцієнтів).

3) медична субвенція (57,4 млрд грн)

Крім того, в Державному бюджеті на 2018 рік передбачено додаткові дотації та субвенції в загальному розмірі 36,5 млрд грн., які безпосередньо стосуються розвитку територій: дотація на утримання закладів освіти та охорони здоров'я (16,5 млрд грн), на формування інфраструктури ОТГ (1,9 млрд грн., пропорційно до площі громади та кількості сільського населення), субвенція на будівництво, ремонт і утримання доріг місцевого значення (11,5 млрд грн), здійснення заходів щодо соціально-економічного розвитку окремих територій (5,0 млрд грн), на окремі інфраструктурні проекти (1,5 млрд.грн).

3 іншої сторони, до розбалансування місцевих бюджетів призводить встановлення на державному рівні пільг з сплати місцевих податків. Так, в кінці 2017 року змінами до Податкового кодексу України для земель залізниць в межах смуг відведення та гірничодобувних підприємств для розробки родовищ та видобування корисних копалин встановлена ставка у розмірі 25\% податку на землю, що суттєво зменшило надходження місцевих бюджетів від плати за землю.

Також існує ряд недоліків системи фрормування власних доходів місцевих бюджетів [2], які зменшують можливість отримання в повному обсязі доходів місцевих бюджетів (податків та зборів) та досягнення реальної бюджетної самодостатності:

- недиверсифрікованість податкових надходжень, основну частку яких становить податок на доходи фізичних осіб, при цьому до 70\% його надходжень в більшості сільських та селищних бюджетах забезпечуються за рахунок оподаткування заробітної плати працівників бюджетної сфери;

- зарахування податку з доходів фрізичних осіб до місцевих бюджетів за місцезнаходженням підприємств, що, враховуючи існуючу в Україні практику реєстрації чи розміщення більшості значних підприємств в адміністративних центрах, призводить до недоотримання громадами податку на доходи тих працівників, які проживають та отримують соціальні послуги не за місцем праці;

- відсутність доступу в органів місцевого самоуправління до даних про фрактичну сплату окремих податків платниками, які перебувають чи здійснюють підприємницьку діяльність на відповідних територіях, що не дозволяє їм сприяти максимальній мобілізації податків та зборів. Разом з недолугою державною політикою встановлення частини соціальних пільг, яка фрактично стимулює приховування доходів та нелегальне праце-влаштування, це призвело до ситуації, коли офіційно працевлаштовані та сплачують податки лише 10,5 3 приблизно 18,0 мільйонів працездатного населення;

- неповнота даних в електронному реєстрі прав власності на нерухоме майно, відмінне від земельної ділянки, виписка з якого є підставою для нарахування податку на нерухомість (за оцінками експертів, на зараз є внесені дані лише $40 \%$ майна);

- сповільненість процесу передачі земель поза межами населених пунктів в розпорядження органів місцевого самоврядування (фактично розпочався лише з 2018 року, за оцінками Мінагрополітики на травень 2018 року було передано лише 20,0 з 760 тис. га).

Разом 3 тим, посилює диспропорції між територіями включення до доходів місцевих бюджетів частини загальнодержавних податків (акцизний податок із роздрібного продажу підакцизних товарів), величина яких безпосередньо не залежить від ефективності управлінських рішень місцевої влади, а є наслідком територіально-географічного розташування території [3].

Основними недоліками системи міжбюджетних трансфрертів, які порушують справедливість фінансового вирівнювання та не відіграють стимулюючої ролі для розвитку $є[4 ; 5]$ :

- залежність механізму розрахунку базової дотації лише від рівня надходжень на одного жителя податку на доходи фрізичних осіб та податку на прибуток підприємств (для обласних бюджетів), що не враховує інші бюджетоутворюючі податкові надходження до місцевих бюджетів, зокрема акцизні податки, податок на майно. В результаті, обсяги базової дотації для місцевих бюджетів з приблизно рівними власними доходами можуть відрізнятися в 8-10 разів. Окремі місцеві бюджети з достатньо високим рівнем власних доходів отримують значні обсяги базової дотації, натомість бюджети з нижчими доходами, але високою часткою в них податку на доходи фрізичних осіб - сплачують до державного бюджету реверсну дотацію;

- недоліки формули розрахунку освітньої субвенції, що не враховує реальний контингент учнів та потреби збільшення педагогічного персоналу, поділ класів на групи при вивчені окремих предметів, видатки на заміну тимчасово відсутніх працівників та інші критерії (за підрахунками Асоціації міст України, дефіцит субвенції лише для міст та ОТГ становить в 2018 році 4,4 млрд.грн);

- несправедливість механізму розподілу субвенції на формування інфрраструктури ОТГ пропорційно до площі та кількості сільського населення - без врахування населення селищ та малих міст, які в багатьох випадках не відрізняються за кількістю жителів чи інфраструктурою від сіл;

- розподіл в ручному режимі коштів Державного фонду регіонального розвитку (ДФРР) та субвенції на здійснення заходів соціально-економічного розвитку окремих територій відповідно до звернень народних депутатів України, органів місцевого самоврядування та місцевих державних адміністрацій, що створює умови для корупції та лобіювання інтересів певних політичних сил. Так, у Львівській області чотири райони, межі яких збігаються з виборчими округами двох депутатів ВРУ від БПП, три роки підряд отримують від 40 до 60\% всього бюджету ДФРР на область, хоча в них проживає лише $12 \%$ населення області. За підрахунками ГМ «Опора», в 2016 році 2,1 з 2,4 млрд.гривень субвенції на здійснення заходів соціально-економічного розвитку окремих територій отримали виборчі округи депутатів-мажоритарників від БПП, «Народного фрронту» та двох провладних депутатських груп, що використовується ними для піару на бюджетних коштах.

Недосконалість критеріїв формування спроможних громад, що призводить на практиці до створення частини громад, об'єктивно нездатних забезпечити належний рівень надання послуг, зокрема у сфрері освіти, культури, охорони здоров'я, соціального захисту, житлово-комунального господарства. Переважання в багатьох випадках політичних чи особистісних мотивів місцевих влад над економічною доцільністю вже призвело до створення малочисельних та неспроможних

Вісник Сумського національного аграрного університету 
громад, які потребуватимуть щоразу більше бюджетних коштів для покриття базових потреб, що створюватиме додатковий тиск на систему міжбюджетного вирівнювання [6;7].

Посилення мотивації місцевих громад до ефективного використання місцевих ресурсів та власних можливостей можливе лише при зміні нормативно-правового законодавства у податкові сфері:

- зміна існуючого порядку зарахування податку з доходів фізичних осіб до місцевих бюджетів за місцем праці на зарахування в місцевий бюджет за місцем фактичного проживання особи, що забезпечить справедливий розподіл надходжень до місцевих бюджетів;

- збільшення частки відрахування в місцеві бюджети податку з доходів фрізичних осіб взамін виключення з їх доходів окремих акцизних платежів, величина яких безпосередньо не залежить від ефективності місцевої влади, а є наслідком вигідного територіально-географрічного розташування;

- розширення прав органів місцевого самоврядування по адмініструванню та контролю за сплатою місцевих податків і зборів; доступ посадових осіб місцевого самоврядування, які займаються аналізом та плануванням бюджету, до інформації про сплату податків та інших обов'язкових платежів фізичними особами;

- впровадження муніципальних фіскальних реєстрів, що міститимуть відомості про нерухоме майно, земельні ділянки та надаватимуть можливість збільшення податкових надходжень для місцевого бюджету; облік учнів, дітей дошкільного віку; громадян, що потребують соціальної допомоги, реєстри осіб пільгових категорій, що дасть можливість оптимізувати видаткову частину та наповнити дохідну частину місцевих бюджетів, проаналізувати обсяги пільг та доцільність їх надання, спрогнозувати необхідний обсяг цільових коштів на повне забезпечення виконання делегованих повноважень.

Усунення недоліків існуючої системи міжбюджетних трансфертів, що порушують справедливість фрінансового вирівнювання та не відіграють стимулюючої ролі для розвитку територій, також потребують змін:

- врахування при розрахунку базової чи реверсної дотацій, поряд з надходженнями на одного жителя податку на доходи фізичних осіб та податку на прибуток підприємств, показників інших бюджетоутворюючих надходжень до місцевих бюджетів, зокрема частини акцизних податків, єдиного податку, податку на майно, що зробить більш справедливою залежність розміру цих дотацій від загального обсягу доходів місцевих бюджетів, а не окремих надходжень;

- прозорість процедур та чіткість критеріїв формування субвенцій з державного бюджету, розподіл коштів яких здійснюється не за формульним підходом, а в «ручному» режимі (субвенція на здійснення заходів щодо соціально-економічного розвитку окремих територій, кошти Державного фонду регіонального розвитку), що зменшить ризики політичної корупції та лобіювання інтересів окремих політичних сил;

- усунення недоліків формул розрахунків субвенцій з державного бюджету, насамперед освітньої субвенції, що не враховує динаміку учнів та реальні потреби освітньої сфери; субвенції на фрормування інфраструктури ОТГ, показник кількості сільського населення при розрахунку якої не враховує мешканців мало відмінних за інфраструктурою селищ та малих міст

Висновки та пропозиції: Формування ефрективної системи місцевого самоврядування в Україні безумовно потребує децентралізації влади. Розпочаті в 2014 року процеси бюджетної децентралізації надали нові можливості місцевому самоврядуванню: самостійне формування місцевих бюджетів, прямі міжбюджетні відносини, розширення податкової бази та ін. Проте, здійснені кроки у сфері децентралізації наразі не вирізняються системністю. Реформування міжбюджетних відносин відбувається при відсутності до цього часу чіткого розподілу повноважень між органами державної влади та місцевого самоврядування. Недоліки системи формування власних доходів місцевих бюджетів зменшують можливість досягнення реальної бюджетної самодостатності. Недосконалість критеріїв формування спроможних громад, політичні чи особистісні мотиви призводять до створення частини громад, нездатних в найближчій перспективі забезпечити належний рівень надання послуг, зокрема у сфері освіти, культури, охорони здоров'я, соціального захисту, житлово-комунального господарства, що посилює соціально-економічну диференціацію в розвитку територіальних громад в Україні.

\section{Список використаної літератури:}

1. Податковий кодекс України. Верховна Рада України; Кодекс України, Закон, Кодекс від 02.12.2010 № 2755-VI. Режим доступу: http://zakon5.rada.gov.ua/laws/show/2755-17/page.

2. Патицька Х. О. Фінансово-економічний потенціал територіальних громад: механізми формування та активізації: монографія / Х. О. Патицька. Львів: ДУ «Інститут регіональних досліджень імені М. І. Долішнього НАН України», 2019 р.216 с.

3. Патицька X. О. Проблемні аспекти формування та розвитку об'єднаних територіальних громад Карпатського регіону. Регіональна економіка, 2019, № 2, с.36-45

4.Пелехатий А.О. Бюджетна політика у забезпеченні розвитку територій: концептуальні домінанти та напрями модернізації: [монографія] / А.О. Пелехатий. Львів: Львівський національний університет імені Івана Франка, 2019. 386 с.

5.Пелехатий А.О. Обгрунтування нової парадигми бюджетної політики розвитку територій в умовах рефоормування публічних фінансів в Україні. Електронне наукове фахове видання «Ефективна економіка», №7, 2019 [Електронний ресурс]. Режим доступу: http://www.economy.nayka.com.ua/?op=1\&z=7191

6.Андрущенко В. Л., Ляшенко Ю. І. Економічні та позаекономічні аспекти оподаткування // Фінанси України. 2005. № 1. C. $36-43$.

7.Панура Ю.В. Узагальнення наукових підходів до визначення сутності податків та їх систематизації. Наукові записки. Серія «Економіка». 2013. Вип. 21. с. 181-184.

8.Петрушенко, Ю.М. Концептуальні основи фрінансування місцевого розвитку в проектах Програми розвитку ООН в Україні [Текст] / Ю.М. Петрушенко, Н.М. Костюченко, Ю.І. Данько // Actual Problems of Economics. Volume 159, Issue 9, 2014, Pages 257-263. 


\section{References}

1.Supreme Council of Ukraine (2010). Podatkovyj kodeks Ukrai'ny [Tax Code of Ukraine] (Adopted on 2010, December 2, 2755-VI). Retrieved from http://zakon5.rada.gov.ua/laws/show/2755-17/page. [in Ukrainian].

2.Patytska Kh. O. (2019). Finansovo-ekonomichnyi potentsial terytorialnykh hromad: mekhanizmy formuvannia ta aktyvizatsii: monohrafiia [Finansovo-ekonomichnyi potentsial terytorialnykh hromad: mekhanizmy formuvannia ta aktyvizatsii: monohrafiia]. Lviv: DU «Instytut rehionalnykh doslidzhen imeni M. I. Dolishnoho NAN Ukrainy», pp. 216. [in Ukrainian].

3.Patytska Kh. O. (2019). Problemni aspekty formuvannia ta rozvytku obiednanykh terytorialnykh hromad Karpatskoho rehionu [Problematic aspects of formation and development of united territorial communities of Carpathian region]. Regional Economics, № 2, pp. 36-45. [in Ukrainian].

4.Pelekhatyi A.O. (2019). Biudzhetna polityka u zabezpechenni rozvytku terytorii: kontseptualni dominanty ta napriamy modernizatsii [Budget Policy in Territorial Development: Conceptual Dominants and Directions for Modernization]. Lviv: Lvivskyi natsionalnyi universytet imeni Ivana Franka, 386 p. [in Ukrainian].

5.Pelekhatyi A.O. Obhruntuvannia novoi paradyhmy biudzhetnoi polityky rozvytku terytorii v umovakh reformuvannia publichnykh finansiv $v$ Ukraini [Substantiation of the new paradigm of budgetary policy of territorial development in the context of public finance reform in Ukraine]. Efektyvna ekonomika - Effective Economics, №7. Retrieved from: http://www.economy.nayka.com.ua/?op=1\&z=7191. [in Ukrainian].

6.Andrushhenko V. L., \& Ljashenko Ju. I. (2005). Ekonomichni ta pozaekonomichni aspekty opodatkuvannja [Economic and non-economic aspects of taxation]. Finansy Ukrai'ny. - Finance of Ukraine, 1, 36-43. [in Ukrainian].

7.Panura Ju.V. (2013). Uzagal'nennja naukovyh pidhodiv do vyznachennja sutnosti podatkiv ta i'h systematyzacii' [Summary of scientific approaches to determining the nature of taxes and their organization]. Naukovi zapysky. Serija "Ekonomika». - Scientific notes. Series "Economics.", 21, 181-184. [in Ukrainian].

Galamay R.Ya., PhD student, Ivan Franko National University of Lviv (Lviv, Ukraine)

Tax decentralization as a factor of formation of financial base of territories.

The article examines the impact of taxes and fees on the formation of the financial base of territories at local, subregional and regional levels. The norms of the main tax revenues to the state and local budgets have been determined. The system of intergovernmental transfers (basic/reverse subsidies, medical, educational and infrastructure subsidies, additional subsidies) and impact on their formation of separate taxes are considered. The system of establishing the privileges for the payment of local taxes at the state level in a rate of $25 \%$ tax is analyzed, which lead to the imbalance of local budgets, namely the privileges for the lands of the railways within allotment of strips and mining enterprises for the development of fields and extraction of minerals. The disadvantages of the system of formation of own revenues of local budgets, which reduce the possibility of obtaining the full amount of local budget revenues and achieve real budgetary self-sufficiency are identified, they are: non-diversification of tax revenues; crediting the personal income tax to the local budgets by location of enterprises; lack of access from local governments to data on the actual payment of individual taxes by taxpayers who are engaged in business activities in the respective territories; incompleteness of data in the electronic register of ownership of real estate other than land; slowness of the process of land transfer outside the settlements to the disposal of local selfgovernment bodies. Methods for enhancing the motivation of local communities for the effective use of local resources and their own abilities are proposed. Suggestions have been made to address the shortcomings of the current system of intergovernmental transfers, which violate the fairness of the financial equalization and do not play a stimulating role for development. It is concluded that the processes of budgetary decentralization started in 2014 provided new opportunities for local self-government, namely: independent formation of local budgets, direct intergovernmental relations, expansion of the tax base. It is necessary to complete administrativefinancial decentralization at all levels of administrative division local, subregional, regional) for the effective completion of the reform.

Key words: taxes, fees, decentralization, territories, intergovernmental transfers.

Дата надходження до редакції: 11.09.2019 p. 